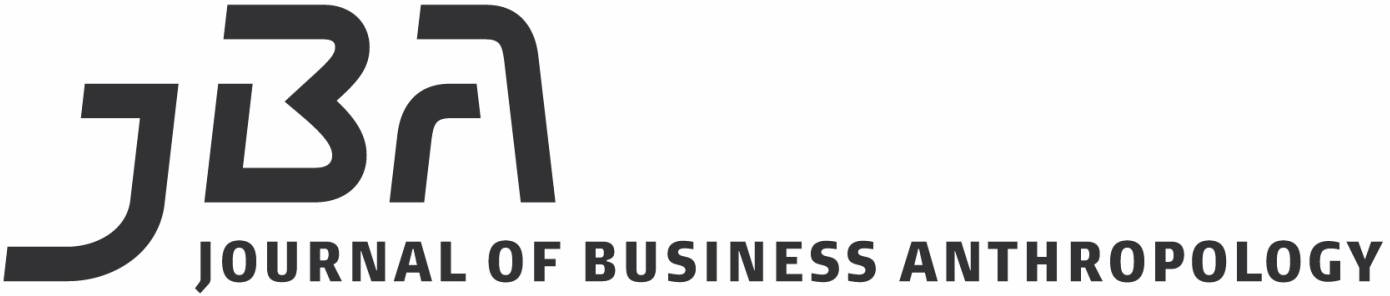

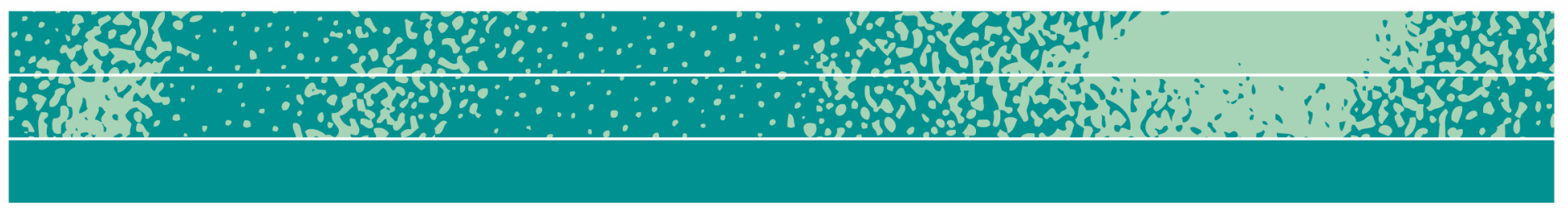

\section{Incorporation and the Morality of Profit in the Business of Cultural Activism}

\author{
Marshall B. Knudson
}

\begin{abstract}
Typical scholarly analyses of ethnic incorporation draw on cases where older, preexisting political entities and their forms of citizenship become the basis for new entrepreneurial corporate identities structured around a set of legal profit-making practices. But what about the cases of ethnic incorporation where ethnicity articulates with legal incorporation without any such prior collective political entity to graft onto? This article draws on ethnographic research with indigenous Mapuche cultural activists to describe and analyze the place of private for-profit and notfor-profit associations in the State-sponsored market for indigenous cultural development work in Chile. Examining the dilemmas that Mapuche activists in Chile face as they pursue legal incorporation in order to access public funds and provide a firmer economic footing to their organizations, it explores the ways that activists negotiate the moral controversies surrounding the place of money, and private-law organizations, in the pursuit of Mapuche collective interests.
\end{abstract}

\section{Key words}

Ethnic Enterprise, Indigenous Cultural Activism, Morality, Profit, Incorporation

Page 1 of 27

JBA 9(2): 354-380

Fall 2020

(C) The Author(s) 2020 ISSN 2245-4217

DOI

$10.22439 /$ jba.v9i2.61

30 


\section{Introduction}

In recent years, anthropologists have examined the dynamics of neoliberalism as a paradigm of political economy and governance on the global scale (Brown 2003, Rose \& Miller 1992, Ong 2006, Shever 2012, Clarke \& Thomas 2006), exploring the articulation of global capitalist rationalities and instrumentalities with local collective identities and group-formation processes, while raising difficult questions about such issues as the incorporation of ethnicity and the ownership and commoditization of culture (Comaroff and Comaroff 2009, Cattelino 2008).

Most scholarly accounts of ethnic incorporation draw on cases where older, preexisting political entities-such as Native American tribal governments in the United States-and their forms of citizenship (such as tribal membership 'enrollment') become the basis for new entrepreneurial corporate (or collective) identities structured around a set of legal profit-making practices, e.g. the operation of tax-free concessions, casinos, and tourist enterprises, the leasing of mining rights, or the licensing of tribal insignia (Bunten 2008, Cattelino 2008, Comaroff and Comaroff 2009; see Bunten 2015).

But what about the cases where ethnicity articulates with legal incorporation without any such prior collective political entity-such as a tribal government-to lean on or graft onto? What is to be made of the predicament of the Mapuche in Chile, where members of an ethnicpolitical group see themselves as a people, in the political sense, though they enjoy no legal recognition to political peoplehood (Rogers 2003) even in the sense of limited sovereignty, such as that ascribed to Native American tribes in the United States? (Barker 2005, 2011).

This article draws on ethnographic research with Mapuche activists in Chile to describe and analyze the place of legal incorporation in the economics of indigenous cultural and political activism in a "nontextbook" situation where there is no clear indigenous political authority. Mapuche are recognized as indigenous Chileans, but many Mapuche contend that they are not Chileans. The article examines dilemmas that Mapuche activists face as they pursue legal incorporation in order to access public funds and provide a firmer economic footing to their organizations, while promoting the collective interests of the Mapuche people. It considers the challenges to relying on private-law organizations to promote collective goods such as cultural preservation and language revitalization, and shows how activists negotiate the challenging process of pursuing legal incorporation and exercising corporate economic rights in the State-sponsored market for indigenous cultural development work in Chile. In analyzing these cases, it makes the claim that Mapuche activists navigate a double bind in order to economically sustain their activities while maintaining their moral integrity, tarrying with concepts 
of moral gain and the widespread discourse of lament over the erosion of cultural integrity through unethical profit-making activities. In the process, it points to ways in which Mapuche cultural activism is affected by the structure of the State-sponsored indigenous development market on the one hand, and powerful cultural discourses of morality, profit, and the status of culture in a world of commodities.

There is a rich history of inquiry at the intersection of morality and the economy in anthropology. Contemporary practitioners can hardly avoid the cornerstone analyses of the gift (Mauss 1925, Godelier 1996), the Kula ring (Malinowski 1922), Potlatch (Boas 1895, Harkin 2001, Seguin 1986), and other early works on non-Western regimes of value, non-market economies, or more generally, the place of the economy in society (e.g. Polanyi 1955, Sahlins 1972). Turning to later and more contemporary analyses of the capitalist market economy, one of the recurring themes that pervades the literature is the notion that capitalism is an immoral-if not amoral-enterprise. From that perspective, alternative ethical paradigms may be identified and even taken as models for a reformed capitalism. This latter theme resonates in concepts such as "the moral economy" (Carrier 2018), the ethical consumer (Harrison et al., eds. 2005), the "certified B-Corporation", and the "social enterprise" associated with Muhammad Yunus (2007), the grandfather of "microloans", all of which appear to present alternative moral logics from within capitalism itself. Forgotten perhaps because of its own banality, the not-for-profit form of association is ex hypothesi also constituted for an alternative purpose to the overarching principle of the economy, that is, profit. Be they constituted for educational, cultural, religious, or otherwise purposes, such associations are recognized as pursuing lawful purposes in civil society.

The groups discussed in this article are composed entirely of Mapuche members, in the sense that they identify as Mapuche, and are identified as Mapuche by others. Most of the people involved in them are also involved in Mapuche political activism, and some of them have fairly impressive pedigrees in the contemporary Mapuche movement, which dates to the late 1980s and early 1990s (Millalén 2006). Nevertheless, all of these activists occupy a fraught position, since they execute the projects of government agencies and receive funding from the State. Their work under contract with State agencies inspires fears of State cooptation in the Mapuche community. At the same time, their paid work exposes them to the charge that they are engaged in the commoditization (and monetization) of culture, a subject widely bemoaned in the Mapuche world today. This vexing dilemma is all the more interesting in the context of widespread recent anthropological interest in the problem of native sovereignty (Barker 2005, Erazo 2013, Simpson 2014). What is to be made of the paradox that indigenous activists, for whom indigenous autonomy or self-determination is the ultimate goal, engage in State- 
funded cultural development projects, competing amongst themselves to 'win' grants or project contracts from the State? Does it matter that some of them do so as for-profit enterprises, and others as not-for-profit corporations? How do Mapuche activists negotiate their entanglement with the State, handle critics in their own community, and position themselves to exercise their own moral agency? (Ahearn 2001, Kockelman 2007, Ortner 2006).

\section{Indigenous Sovereignty, Commodification, and "Profiting off the Culture"}

Claims to sovereignty, often couched in the language of 'autonomy', abound in the Mapuche community today, and yet, as a legal matter, the Mapuche appear to have little to none (Millalen P. 2006, Verbara et al. 2013). Their status as an indigenous people is protected by a limited number of national laws and international accords (e.g. ILO 169, ratified by Chile in 2009), but their claim to political peoplehood is not. They have no government, central leadership, or territory, aside from the collective land titles that legally ground 3,000 different small reservation communities, or lof, in the 8th, 9th, and 10th regions of Chile, with a total population estimated in the area of a quarter million individuals (Bocarra 2002). Meanwhile, the lion's share of those who identify as Mapuche are residents of urban areas, first and foremost the Chilean national capital, Santiago, the main historic and contemporary destination for Mapuche migration from the rural south (Bengoa \& Caniguán 2012).

For Mapuche cultural activists, the commodification of 'traditional' culture and concomitant loss of control over the conditions of cultural reproduction represent immanent threats to Mapuche peoplehood as serious as the threat posed by the expansion of agroforestry interests and hydroelectric dams in and around Mapuche communities in the south, and as important as the struggle to reclaim usurped community lands (Di Giminiani 2018). In recent years, anthropologists have examined a range of commodification processes, from the commodification of water (Kaplan 2007) to the commodification of intimacy (Constable 2009), language (Heller 2010), selfhood (Urcioli 2008), social personae (Bunten 2008), blackness (Collins 2008), and most germane here, 'traditional culture' (Nash 2000, Wilson 2003), a subject of growing anthropological interest with the ascendance of globalization (Appadurai 1996, Mazzarella 2004) as a widely held characterization of the contemporary political economic predicament in the post-Cold War era. The commodification of culture, an old bugbear of Marxist theoreticians (e.g. Lukács (1971) [1923], Horkheimer and Adorno [1947]) has more recently received most sustained ethnographic attention in the study of ethno-tourism (Harkin 2001, Ryan 2005, Chambers 2010), and in research on the ownership of Native American cultural heritage, including 
physical elements like wampum belts, but also abstract forms such as tribal symbols and insignia (Black, 2002, Bruchac 2018, Brown 2003, Coombe 1998).

Drawing on 24 months of research with Mapuche people involved in activities to promote the Mapuche language and culture (hereafter, "Mapuche activists"), this article pursues this line of inquiry on the commodification of culture by offering an ethnographic perspective rooted in the analysis of vernacular discourse on the morality of profit and private law incorporation among members of an indigenous people in the midst of ethno-national revival. As a preliminary description, however impressionistic, the discourse on the morality of profit discussed here is one in which a putative moral hazard, el lucro ('profit'), is pitted against the integrity 'traditional' culture, conceived as a kind of collective patrimony, which it damages by mere association. Profit spoils culture. The very syntax of the common expression "lucrar con la cultura" ('profiting off the culture'), itself part of a much wider register (Agha 1999) of lament about the erosion of cultural integrity in the Mapuche world, evokes the gist of the moral problem here: using culture as a means to an end.

But the Mapuche do not live in an ethnic vacuum; whether their home is in the city or the countryside, they live among non-Mapuche and share much the same world as their wingka neighbors. The Mapuche moral discourse against ill-gotten profit has a strong intertextual linkage (see Briggs \& Bauman 1992, Agha \& Wortham 2005) to the critique of profit-making in Chilean society popularized by the historic student-led education reform movement of the early 2010s, which coalesced into a campaign against for-profit enterprise in higher education (Mayol 2012, Bellei 2013). Set against this social tableau of national reckoning with Chile's neoliberal inheritance and the status of collective goods like public education, many Mapuche in Chile are broadly suspicious of private enterprise and wary of its corrosive effects on their collective goods, including cultural and linguistic heritage, lands, and claims to political peoplehood (Smith 2001, Brubaker 2004), a stance they also have toward the Chilean State and the neo-colonial domination and violence it represents (French 2012, Scheper-Hughes \& Bourgois 2004, Mallon 2005).

Nevertheless, the Chilean State offers unrivalled economic opportunities for Mapuche activists committed to Mapuche cultural revitalization and ethnopolitical struggle. However ironically, the State indigenous development programs provide Mapuche activists with the potential economic basis with which to dedicate their time to the Mapuche cause through language education and advocacy. But the morality of making contracts with the Chilean State, and taking money from it, appears to erode the claim to autonomy that is so cherished in the discourse of Mapuche ethnopolitics; for some, it is proof positive of 
dependence, or heteronomy, as Kant (1996) called it. And while the morality of profit-making ( $e$ lucro) is not at stake, as such, there is a lot of talk among Mapuche activists about "profiting off the culture", i.e. working in the area of indigenous culture and receiving checks from State agencies. There are questions about the moral integrity of people who would work in the area of indigenous cultural development. More fundamentally, there is a sense that the culture would be damaged or otherwise diminished by contact with the profit motive. Indifferent to their concerns, however, Mapuche ethnic insignia circulate freely in Chile, where they adorn the labels of wine bottles and feature heavily in the names of businesses of all kinds, from tour agencies and liquor stores to homeopathic pharmacies and restaurants. Nor is there presently any legal restriction against the commercial appropriation of Mapuche insignia in Chile. Anyone who has been to Chile in the last ten years can attest that such appropriation is legion.

During participatory research with Mapuche activists in 20162018 , the problem of mixing profit and culture was widely and frequently discussed. Consider data from an interview conducted with Pancho, a young Mapuche man from Santiago whom the researcher met during a weekend language retreat in the south of Chile. In the interview, recorded two months after that initial meeting, Pancho reacts to one of the ideas that had been floated during the retreat, the strategy of reversing language shift by stimulating the use of the Mapuche language in domains of everyday life long dominated by Spanish. He says that a lot of Mapuche people subscribe to the idea that the culture should be insulated from the domain of business and profit-making. Mapuche are resistant to the idea of using Mapudungun for profane, wingka (Chilean) associated domains of life, he says. Nevertheless, Pancho has learned that, from a fairly well accepted sociolinguistic standpoint, the 'vitality' of a minoritized language is depends on the functional domains of human life in which its use is widely appropriate and expedient. Therefore, excluding the domain of business and profit would mean reducing the dominance of the language in the speakers' everyday lives, perpetuating the Spanish-dominant diglossia (Ferguson 1959, Fishman 1967) of the Mapuche population. So however much this metalinguistic (Jakobson 1960) framing of the Mapuche language as valuable and vulnerable to corrosion appears to elevate its status by morally insulating it, even sacralizing it, Pancho has grown convinced that popularization represents more a loss than a gain for the sociolinguistic vitality of Mapudungun. ${ }^{1}$

(P) Yo no creo que ellos tampoco son de la idea...
(P) I don't think they share the idea that...

\footnotetext{
${ }^{1}$ In all transcripts, the use of (M) indexes the researcher as speaker. Other letters (X) correspond to research participants whose names are spelled out by the surrounding prose commentary on the transcript.
} 
De que algún día, Mapudungun sirva para, eh, de, de, como fue la ejemplo, por ejemplo, las cosas que le convienen a una empresa, o sea se mueren.

(M) Haha

(P) Como es posible de que vayamos hablar, en

Mapudungun, de-

(M) Claro.

(P) Sobre los beneficios de una empresa! ¡No se puede hablar de eso!
That one day, Mapudungun should serve as, uh, what was the example, for example the things of importance to a business, I mean they would die.

(M) Haha

(P) How is it possible that we should speak, in Mapudungun, of-

(M) Right.

(P) About the profits of a business! You can't talk about that!

In the transcript, Pancho imagines how Mapuche people who subscribe to the rigid separation of the sacred (Mapuche heritage language and culture) and the profane (the everyday language of capitalism in Chile) would react if someone were to mention the idea that Mapudungun should be the language of business, the language of profit. "They would die", he says, evidently on the verge of laughter. To illustrate how "they would die", he performs a species of mock outrage, enacting a distinct semiotic figure of personhood (Agha 1999) through the conjunct production of exaggerated volume, raised pitch, plus certain grammatical and lexicosemantic elements the sanctimonious question tag, "Como es possible" ('How is it possible') and the stark binary contrast presented between the sacred (Mapudungun) and the profane (business profits), followed by a categorical expression of forbiddance, "you can't talk about that!"

In Pancho's telling, Mapuche culture (i.e. the Mapuche language) is a perishable, and scarce, collective resource (Errington 2003, Moore 2010), analogous to the natural resources of southern Chile that Mapuche communities have long resisted the private exploitation of (PalominoSchalscha 2018, Briones 2007). This is a common trope for talking about Mapuche culture in the Mapuche world: like natural resources, it requires care and management. There is a language of risk that has developed about teaching Mapuche language and culture. The idea is that exposing the Mapuche language and culture by teaching, or otherwise exposing it to, the wrong people threatens the integrity of the culture, for which reason one often hears expressions, or better, exhortations, 'to protect the culture' ("resguardar la cultura.") But as will be clear in the next section, the call to protect the culture is articulated through the practical 
exigencies of doing the work of cultural protection, starting with the problem of funding such work. For this reason, the Chilean State plays an outsize role in the process, creating a moral quagmire for Mapuche activists working in the cultural sector.

\section{Indigenous Governmentality and Private-Law Associations}

Established through the framework of the "Indigenous Law" of 1993, CONADI is a Chilean government agency that funds competitive grants for projects actionable in the field of indigenous development, a field which includes things such as Mapuche language education, weaving, ceramics, silverwork, ancestral sports and games programs, etc. Also relevant for indigenous people, given the funds they furnish for similar cultural education projects, are the Ministry of Culture (formerly the Consejo de la Cultura y las Artes) and the Ministry of Education. While some State funding earmarked for indigenous people is absorbed directly by individuals, as in individual grant competitions for projects in the arts, for instance, or the beca indígena ('indigenous scholarship) for university study, most funding is ultimately disbursed not to natural persons but to legally registered entities commonly referred to by their initials, "P.J.", for personalidad jurídica ('legal personhood'). In order to be eligible for State money for their projects, then, Mapuche must obtain legal personhood by formalizing their associations, either as not-for-profit corporations or foundations, which are designated by the Chilean laws of association, or as for-profit indigenous consultorios, a type of entity laid out in the socalled "Indigenous Law" of 1993, to execute government-funded projects in the field of indigenous development. While a P.J. enables Mapuche activist groups to better access resources, legally establishing an instrument distinct from the natural persons who found it, it also entails fiduciary responsibilities that expose the organization's officers to public scrutiny and legal liability.

The distinction between for-profits, such as consultoras, and notfor-profits, such as corporaciones, conceals the fact that both kinds of entities are legally endowed with economic rights to spend money and incur debt. Both serve economic functions, employing Mapuche people to engage in Mapuche-directed activities. Above all, the different for-profit and not-for-profit entities involved in the ecology of State indigenous governmentality (Foucault 1991, Gustafson 2009, Postero 2007) are linked by the same, almost inexorable need for the economic resources that often only the State can provide. ${ }^{2}$ The State creates economic opportunities for indigenous cultural activists, which has resulted in the formation of a small professional class, however precariously employed,

\footnotetext{
${ }^{2}$ Viewed as a subset of the Chilean population, Mapuche are poorer and more precariously employed, making it quite challenging for Mapuche activists to raise money from within their own social networks (see e.g. Cerda 2009).
} 
that specializes in the area of Mapuche cultural development. ${ }^{3}$

The profit-motive distinction also occludes the fact that, in folk discourses about the morality of making money, the legal status of an organization generally matters less than the manner in which it makes money and pays its members. Consider an alleged case of "profiting off the culture". In the following vignette, we hear from two friends who work at a for-profit consultora ['consultancy'] and a not-for-profit corporación ['organization'], respectively. They are discussing, or rather griping to the researcher about, the hostilities they face from certain quarters of the Mapuche world. Both have been called "vendidos" ('sellouts') for doing paid work with the State, but Arturo, who works at the consultora-unlike his friend Milla at the not-for-profit organizationclaims he cannot be accused of hypocrisy, since profit is explicitly the purpose of his operation. To people like Arturo and Milla, both types of legal forms of association operate with money and pay individuals for work rendered. Likewise, in the framework of government-funded projects and work contracts, they operate in broadly the same way, applying for funding in a competitive annual cycle of solicitations for applications to do certain kinds of work, broadly construed. From this standpoint, both men could be targeted by accusations of immoral profiteering, lining their pockets by selling 'the culture' for government contracts.

(A) El Patricio no pesca al Milla, el Milla dijo: "qué, ese hueón", así como en mala onda con el Patricio,

Qué, ese hueón es él que anda transmitiendo que gastamos como 10 millones".

Y Milla dijo: "pero los internados que hacen estos huevones, el ministerio igual les pasa cuestiones", e igual son lucas que están como encubiertas po
(A) Patricio doesn't call on Milla, y and Milla said, "what? that guy?" like he was dismissive of Patricio,

"What, that guy is the one going around saying that we spent like 15 thousand dollars!"

And Milla said: "but the language camps that those guys do, the ministry still passes them money", and after all, it's cash that's like hidden, man.

\footnotetext{
${ }^{3}$ While this article focuses on activists involved in formal associations, or in attempts to formalize them through incorporation, there are many other ways in which the State supports Mapuche people to do Mapuche projects. In addition to indigenous 'subaltern bureaucrats' (Park \& Richards 2007, Radcliffe \& Webb 2015), another important group are indigenous teachers employed in public education through the 'Intercultural Bilingual Education' program of the Ministry of Education. Indigenous teachers, referred to as "traditional educators", are a numerous and variegated group employed in rural and urban areas, both in metropolitan Santiago (and Valparaiso), and in the south (see Luna F. 2015, Luna F. et al. 2017, Ortiz 2009.)
} 
hueón.

Y parece que ahora están trabajando en un proyecto con el ministerio.

Pero el Milla decía: "yo no puedo hacerme el tonto si me pasaron las lucas, las lucas había que gastarlas po."

"Yo no podía devolver esa plata, esa plata estaba ahí y había que gastarla."

E yo le dije: "pero esa hueá te deja a ti mal parado porque tú eres de una organización. Yo te lo dije cuando partiste, que tú no eras una empresa, tú no eras una consultora, tú eras una hueá social.

Por tanto, si tú te metes con temas de plata, ¿qué es lo que te iba a decir la gente? "Este hueón se vendió por la plata po hueón!"

A diferencia de mí, que yo era una empresa y yo muevo lucas, y a mí el hueón que me diga alguna hueá, es porque yo, puta es lucro po, por último, es lucro y yo lo dejo claro: es lucro.

El tema es que tú no po, tu eres una organización social y tienes que cuidarte de eso.
And it seems that now they're working on a project with the ministry.

But Milla was saying: "I can't act like a fool if they pass me money, the money had to be spent, you know."

"I couldn't return that money, that money was there, and it had to be spent"

And I told him: "but that stuff leaves you looking bad because you are from a (non-profit) organization. I told you when you started, that you weren't a business, you weren't a consultora, you were a social thing."

Which is why, if you get mixed up in issues of money, what are people going to say about you? "This guy sold out for money, man!"

Unlike me, as a business I move cash, and to me anyone who should tell me something like that, it's because I, heck it's profit, man, it's profit and I say it loud and clear: it's profit.

The thing is you can't man, you're a social organization and you have to be careful with that.

In his recollection of the conversation with Milla, Arturo frames himself as both consoling his friend ("you're not a bad person") and chiding him for his errors ("you've sought after people who don't give you the time of day, because you've been unfriendly, sometimes you've made fun of certain things, you took yourself too seriously.") Arturo mentions a 
third Mapuche activist, Patricio. Milla accuses Patricio, who belongs to a rival organization, of spreading a story that Milla had received an inordinate amount of money from a government agency in order to spend it on an activity that could have been executed with just a fraction of that sum. Milla is the target of a story about profiting off the culture and must realize that his public reputation is at stake, potentially putting his livelihood at stake too. He responds to this allegation of profiteering by declaring that he was obliged to spend the money earmarked for his project; he had no choice. He also says that Patricio is part of an organization involved in its own questionable dealings with money earmarked for indigenous development programs. In effect, he deflects the allegation against him back on his accuser. Arturo seems to brush aside this defense, reminding Milla that he is part of "a social thing", and later, "a social organization". When it comes to money, Milla, as a member of a not-for-profit, is constrained by a different form of accountability than Arturo, who claims the benefit of being part of a for-profit entity where he enjoys the freedom to declare that his work "[is] profit, man, it's profit and I say it loud and clear: it's profit!"

Arturo's counsel suggests that for a not-for-profit in the indigenous cultural development sector, the very appearance of profitmaking could damage the organization's public reputation, potentially swaying government functionaries from further involvements with it. But there is another perspective on the moral discourse of profit and culture in the Mapuche community, which frames profit as immoral in all cases when it is generated from cultural work, and sees private organizations as inappropriate for collective goods. Consider the following interview swatch with Raimundo, a young Mapuche activist in his mid-30s of lof (reservation) origin who now lives in the city, and recounts his earliest experiences participating in activities centered on the Mapuche language, Mapudungun. As Raimundo tells it, several years before our interview, after meeting a few other language activists in the city of Temuco at a street march to promote the officialization of Mapudungun by the regional government, he got involved in the formation of a Mapuche notfor-profit organization dedicated to the promotion of the Mapuche language, in the widest sense of teaching, learning, speaking, recording, publishing, campaigning, and so on. He was a late addition to an informal working group that was engaged in a longwinded consultation process with representatives of a government ministry, discussing the status of Mapudungun and possible policies to mitigate language shift (Fishman 1991) towards Spanish. The ministry had proposed the establishment of a corporation for the language, a language institute.

(R) El cuento es que también (R) supe que bueno, el estado intentaba armar este instituto,
(R) The story is that I knew that, well, the State was planning to set up this language institute, 
Pero yo no veía esa voluntad de que iban a armar el instituto porque yo más bien lo veía como un negocio

La consultora "tanto" se adjudicaba la plata, hacían un par de trawünes y quedaba en nada.

Y al otro año lo mismo, al otro lo mismo...
But I didn't see the will to set up the institute, because I saw it more as a business

\author{
"Such-and-such" consultancy \\ managed the money, they would \\ do a pair of trawünes \\ ('meetings') and it would end up \\ in nothing.
}

And the following year the same thing, and the next the same...

The consultation process was interminably long, and ultimately fruitless. Raimundo contends that it felt "like a business". He explains how the indigenous consultoras would organize the consultations with Mapuche people on behalf of the State and get paid handsomely for it, regardless of the outcome of the consultations. Meanwhile, in his view, the representatives of the State never demonstrated the will to move forward with actually creating such a Mapuche language institute.

(M) Pero porque no se veía mayor interés en concretarlo?

(R) No. Sentí que era como un negocio, y eso era.
(M) But because you couldn't see much interest in carrying out the plan?

(R) No. I felt like it was a business, and that's what it was

Raimundo's revelation about the nature of the indigenous consultation process, that it is a business, implies that the explicit motives for indigenous consultation bely the underlying structure-the organized exchange of money and services (pertaining to indigenous cultural development). As mentioned above, this account of business plays favorably to a widely known trope that profit (and business, or profitseeking) is fundamentally immoral (or amoral). To Raimundo, the Statesponsored process ostensibly designed to benefit the Mapuche people by targeting its heritage language for investment, ultimately did not appear to achieve any greater goals than letting money change hands between the State and its clients. Raimundo's main concern, as he explains it, is not so much the indefinite bureaucratic foot-dragging (which he also bemoans), but rather the profit-making that he sees going on, in spite of an evident lack of results. 
(R) Nosotros por cuenta propia empezamos a reunirnos, empecé a conseguir gente...

Después de unas cinco reunions creo, resolvimos de que sí, teníamos que constituirnos, empezamos a averiguar cómo se constituía y, fue trámite el resto, puro trámite.

Armamos la corporación, se hizo el lanzamiento...
(R) By our own means we started to get together, I started to get people to join...

After some five meetings I think, we resolved that yes, we had to constitute ourselves. We began to look into how that was done and, all the rest was just procedure.

We put together the corporation, we did the launch...

In reaction to the apparent futility of the government agency's indigenous consultation process over the concept of a language institute, members of Raimundo's working group started meeting on their own. They soon decided to form a not-for-profit corporation and prepare for a public launch. From the beginning, there were critics of the legalization of the group as a not-for-profit corporation. One high-profile Mapuche political activist expressed a strong public opinion against the idea, and his influence threatened to turn others against it as well.

(M) ¿Qué pasó con eso?

(R) Se había opuesto, y quería sacar un comunicado. Y creo que el día anterior, había sacado comunicado. Yo leí el comunicado y...

(M) ¿Él estaba involucrada en un momento en el proceso?

(R) Eso no lo sé. Supuestamente sí, pero yo ni lo conocía.

Solo sabía quien era y solamente fue como: "Y qué se viene a meter si él no ha estado trabajando aquí!"

Y bueno, además que, las
(M) What happened there?

(R) He had been opposed, and wanted to issue a public statement. I think the day before he had issued the statement. I read the statement and...

(M) Was he ever involved in the process?

(R) That I don't know. Supposedly yes, but I didn't even know him.

I just knew who he was, and it was just like: "That he should show up and stick his head in the issue when he hasn't been working here!"

And well, in addition, the 
acusaciones eran como falsas entonces, eso me dio más rabia, porque eran falsas.

(M) ¿Qué dijo?

(R) Que el instituto era de un partido político. Después dijo que en el instituto no eran hablantes, y nosotros éramos hablantes.

Y como que, todas las cosas que dijo eran falsas. accusations were like false so, that angered me, because they were false.

(M) What did he say?

(R) That the organization belonged to a political party. Afterwards he said that in the organization there weren't any speakers, and we were speakers.

And so, like everything he said was false.

According to Raimundo, the elder Mapuche activist critic was explicitly opposed to the idea of creating the language institute, basing his opposition on a number of false attributions about Raimundo's group. The critic claimed that the group participating in the design of such an institute was, in fact, controlled by a political party, a claim that if true, would undermine the future institute's claims to institutional autonomy, not to speak of any claims it might make to represent the Mapuche language community or its concerns. As if this were not enough, the critic also alleged that there were no (Mapudungun) speakers among the group's members, a claim that if true would challenge any pretense it might have to epistemic authority in matters of Mapudungun. Both of these allegations were false, Raimundo says. These two allegations are defeasible, because they can be falsified simply by investigation and the examination of the evidence. But the core contention of the elder activist critic appears to be an ideological, rather than factual, matter.

(R) Ah, que fuera de derecho público, no derecho privado.

Ya, y derecho privado era como privatizar la lengua, esa fue su acusación, "están privatizando la lengua”, de lo que recuerdo.

(M) Ya.

(R) Porque, claro, entonces nosotros dijimos, "derecho público...entonces que la haga
(R) Ah, that it should be a public entity, not a private one.

$\mathrm{Ok}$, and private meant like 'to privatize the language', that was the accusation, "you're privatizing the language!", is what I recall.

(M) Right.

(R) Because, right, so we said, "public law...[meaning] it should be done with CONADI? But that 
con la CONADI? Pero eso

significa que el gobierno de turno va a poner a su gente ahí, $\mathrm{y}$, va a ser lo mismo".

Entonces, nosotros defendimos la idea de hacer una corporación de derecho privado,

Básicamente que nosotros mismo teníamos que decidir a quiénes íbamos a tener ahí,

Para mayor control por parte de nosotros mismos. Era como ese el discurso. means that the government in power will put its people in there, and it will be the same thing".

So, we defended the idea of making a private-law corporation,

Basically, that we ourselves would have to decide who we would have there,

For greater control on our part. That was the discourse.

The political question of authority and control is what's at stake in this dispute. The critic's claim is that enacting a private-law organization for Mapudungun would privatize the language and take it out of the hands of the public, the people. For Raimundo, creating a public-law entity would mean submitting to the control of whatever government should happen to be in power.

The critic argued that an institute for the Mapuche language should be a public entity, not a private-law one. "And private means privatizing the language, that was the accusation, 'you're privatizing the language,'" Raimundo says, ventriloquizing the critic's speech with an affected voice.

This episode, involving an accusation of privatizing the language, suggests that the language is an object of the same kind as the more typical objects of privatization: State enterprises, (indigenous) collective land titles, and so on. Privatization is routinely bemoaned in leftist political discourses, for instance, and was a keyword in the 1970s and 80s with the Pinochet regime's efforts to convert the inalienable, collective land titles of lof reservation communities into private, alienable lands (DiGiminiani 2012, Taylor 2006, Richards 2013). As a result of this recent historical background, the accusation of engaging in that transformative process called privatization is loaded with prior meanings, and evocative of profoundly negative feelings.

Rather than accept the elder activist critic's false accusation, of course, Raimundo and his comrades counter that their pursuit of a private-law institute for the Mapuche language would mean that, "we ourselves would decide who we would have there, for greater control on our part." "That was the discourse", he says. Where public control denotes the State, private control is framed, among Raimundo's 
groupmates, as the autonomous alternative. Recall that in Chile, the Mapuche enjoy no political recognition and have nothing even approximating a Native American tribal government in the United States. Private-law associations provide a way that Mapuche groups, united by social interests like cultural development, can provide a stable structure of employment for its members and a node of structure in the field of Mapuche cultural activism. This crucial fact belies the expectation, held by many individuals such as the elder Mapuche activist critic of the CONADI institute proposal, that a language institute for Mapudungun be a publiclaw entity. In this case, private associations are the drivers for Mapuche cultural development, however much public agencies like CONADI and government ministries provide the critical infrastructure.

In spite of the critics, Raimundo's organization eventually incorporated successfully. In many cases, however, attempts at incorporation never get off the ground.

\section{Incorporation and the Morality of Money}

Whereas the previous ethnographic vignette relates an attempt at incorporation that ultimately succeeded, in spite of external critics, the following case depicts a failed attempt at incorporation that was hobbled by internal rifts among the would-be founders over questions of money and morality.

A group of urban Mapuche in Santiago is convening their first meeting to discuss the steps to take in order to incorporate, forming a formal association under the law. Their motivation for this path of action is the shared sense that their language and culture is being distorted and exploited by unscrupulous individuals motivated more by profit than by Mapuche pride or politics, who have created private non-profit organizations to tap into State indigenous development funds. Beyond this shared concern, the group's members have many differences between them. In the course of their meeting, certain points of interactional tension arise, in particular, over how the organization should be designed, what work it should engage in, and how it should relate to money.

The group's members are all apparently keen on the group being an authentically Mapuche group, but they have differences of opinion as to what would suffice for that to be the case (see e.g. Zorn 2004). One idea is for the Santiago based group to acquire outright, or at least secure access to, a place in the rural south, 500 miles away or more, for urban members no more than a handful of whom are in possession of automobiles, to conduct business. There is talk of building a ruka ('house') there in which to hold meetings and receive guests. This idea is scrapped for its unfeasibility. Another proposal is to have a properly Mapuche modality of leadership in the organization. The group will need 
a longko ('head', 'leader'), it is agreed, but opinions seem to be split over whom to elect for the important title.

A middle-aged woman very stridently criticizes the place of money in Mapuche organizations and insists that their organization not become oriented around it. A young man responds that dealing with money is simply part of the work, the result of successful proyectos, grants for specific, executable projects. "We can't blind ourselves to it", he says. An older man speaks up supporting that notion, pointing out that without such money, the group's projects would never make it from planning to execution. In order to get such money, however, the group will have to compete, as a legal organization, with other such organizations, including the unscrupulous profiteers whom they have organized to work against in the first place.

A member of the group named Maria, a middle-aged woman of modest means who had to travel nearly an hour and a half in bus in order to attend the meeting, compares herself against Inés, a woman who has come to be regarded as an icon of unscrupulous profiteering in the field of Mapuche cultural development. "She has [university] degrees, she has this language organization that just won a grant worth 70,000 dollars, you feel inferior..." says Maria, as she shares the worry that Inés' so-called language institute will soon have even greater power if CONADI grants it the authority to certify teachers of Mapudungun for the whole city. Inés' language institute is organized as a not-for-profit, but from the standpoint of Maria and others in the group, that legal distinction hardly matters, since the not-for-profit is just a shell for the unscrupulous individual gains of its members.

Another member of the group in attendance, a middle-aged man named Santiago, speaks up with a forceful, but measured delineation of the problems with the profiteering language institute. Above all, there aren't' any speakers in the organization, he points out. "A lot of times that gets dressed up", he says, suggesting a gap between appearances and underlying facts. The lack of legitimacy ascribed to publicly funded organizations stems from the contradiction between the characteristics of the individuals involved, and the ostensible purpose behind their legal incorporation. The new group considers this established language institute to be illegitimate, because it counts no speakers among its ranks. After all, it is asked, how should a Mapuche language institute function without any speakers (or linguists)? It seems to be another case of unscrupulous profiteering in the field of indigenous cultural development, they reason.

Here, in effect, an emerging group on the path forming a legal organization looks to compete against another established group that is already legally incorporated, in order to diminish its influence and ensure that policies which affect the Mapuche language in the metropolitan 
region be guided by Mapuche speakers.

Sometime after the meeting to create a legal association for the promotion of Mapudungun in the city, an activist named Josefa described what had happened at the group's subsequent meeting that the researcher was unable to attend, and which proved, fatefully, to be its last.

(J) Terminaron peleando, hueón...

(M) Sí, sí caché.

(J) Terminaron peleando, yo caché que después se dividieron, no se pusieron de acuerdo.

Unos querían formar una fundación, otros querían formar una corporación,

Y al final se terminó disolviendo la hueá y ahora quedaron todos botados.
(J) They ended up fighting, man...

(M) Ya, I heard.

(J) They ended up fighting, I found out that afterwards they got divided, and couldn't come to agreement.

Some of them wanted to form a foundation, others wanted to form a corporation,

And in the end it dissolved and now they've all ended up dispersed.

In this brief account of the fate of the effort by Mapudungun speakers like María and Santiago to start a Mapuche language organization in the city, Josefa relates how the would-be organization's founding members came to irreconcilable differences. Strikingly, in Josefa's account, it was the question of what legal form the group should take that generated its dissolution: "some of them wanted to form a foundation, others wanted to form a corporation." Mauricio, a Mapuche man in his early forties, participated directly in the group's meetings and identified a somewhat different motive for the infighting than that which Josefa described. For Mauricio, the problem wasn't about what kind of not-for-profit to form, but rather, revolved around suspicions about money. Mauricio said that some members of the group had come to push the idea of hiring a lawyer to give them legal counsel and assist them with the process of incorporation. Other members of the group alleged that the person whose idea it was to hire the lawyer was making a thinly concealed attempt to help out a friend in the legal profession. Members of the group who had prior experience working with lawyers, such as those who with labor union experience, were suspicious of the proposal, and there was a loss of confidence between the emerging factions in the group. The suspicions harbored about opposing organizations' members and their motives were replicated within the group itself, eventually tearing it asunder. Through 
the different accounts of Maria and Santiago, Josefa and Mauricio, a vivid picture emerges of how questions of profit-making and monetization play into the social drama of Mapuche cultural activism today, weighing on Mapuche organizations even before they can successfully incorporate.

\section{Final Remarks}

Mapuche language and culture activism is a thoroughly political enterprise closely linked to projects of Mapuche peoplehood. Less obviously, perhaps, it is also an economic enterprise, since activism involves programs and activities that require human labor, materials, and physical infrastructure, all tied to the flow of money. That flow is constrained by activists' abilities to procure funding through relevant sources, foremost of which are State agencies. Yet another source of constraint comes 'from below', in the form of folk moral discourses about profit-making and preserving the sanctity of 'the culture' from the profanations of profit, el lucro.

The folk morality of profit-making described here in respect of Mapuche people in Chile rubs elbows with E.P. Thompson's (1971) notion of the moral economy, as he developed it in an article on the English crowd in the 19th century, and with James C. Scott (1976) writings on the moral economy of peasants in southeast Asia. As in their respective contributions, this essay describes popular, or 'folk', practices that track an alternative pattern of cultural motion (Urban 2001) to the powerful mediatized institutions (Agha 2011) of the centralized Chilean State and the state-centric ideologies of governance sustaining it. While the Statefocal perspective on incorporation points up the legal parameters on the practice of profit-making, Mapuche folk discourses about the morality of profit in the ambit of culture dissolve the for-/not-for-profit distinction by projecting a distinct model of illicit profit-making: ill-gotten gains made at the expense of Mapuche culture. Unlike in the work of Thompson or Scott, the analysis presented here is focused on folk practices that, while undergirding popular, subaltern moral economies autonomous of the State, also link folk moral discourses with the redistributive mechanisms of the State indigenous development complex in which Mapuche ethnic entrepreneurs participate via a thoroughly 'neoliberal' system of competitive project solicitations open only to properly constituted legal entities. This is not a straightforward story of indigenous sovereignty, but in part, an account of the obstacles to autonomy presented by the reliance on State funding for gainful employment in the area of indigenous language and culture. The morality of profit becomes a linchpin in the social drama of Mapuche peoplehood and the struggle for the protection and promotion of Mapuche cultural heritage.

Activists face a classic double bind situation (Bateson et al. 1956, Cattelino 2010): if they work with the State, then they will be tainted by 
the association, and subject to possible allegations of cooptation. But if they work autonomously, relying on the generosity of the community, then they will almost certainly go broke before they make any headway. The individuals will go their separate ways in search of other opportunities for work to 'pay the bills'. This article has suggested ways that anti-State Mapuche activists navigate the tension between their public stance toward the State and their actual entanglement in Chile's indigenous governmentality complex. The paradoxical use of private-law entities to achieve public-law ends demonstrates a minor form of sovereignty. The constellation of Mapuche legal associations, for- and notfor-profit, saturate a space of competition over authority and expertise in technical cultural matters.

The morality of profit is an important contemporary issue not confined to indigenous peoples facing the pressures of the global market and the national State. For instance, there has been no paucity of interest in the subject of profit among American business writers. Indeed, popular press publications about profit proliferate, with straightforward titles that speak to the tensions between doing good and making profits, including, inter alia, Investing for Change: Profit from Responsible Investment (Landier \& Nair 2008), Do Good: Embracing Brand Citizenship to Fuel Both Purpose and Profit (Thompson 2017), The Moral Case for Profit Maximization (White 2009). Nevertheless, anthropologists seem to have hardly begun to explore the morality of profit and all the fascinating social questions surrounding it in different ethnographic contexts around the world. As the global economy pitches toward a deep recession and the prospect of even starker wealth inequalities, as well as new social movements to challenge them, anthropologists would be well positioned to track the ways in which ideas about profit are germinated, circulated, and refashioned in the crush of social life.

\section{References}

Agha, A. 2011. "Meet Mediatization." Language \& Communication 31(1): 163-170.

1999. "Register." Journal of Linguistic Anthropology 9(1-2): 216-219.

Agha, A., \& Wortham, S. 2005. "Discourse across speech-events: Intertextuality and interdiscursivity in social life." Journal of Linguistic Anthropology, 15(1): 1-150.

Ahearn, L. 2001. "Language and Agency." Annual Review of Anthropology 31: 109-137.

Appadurai, A. 1996. Modernity at Large: Cultural Dimensions of Globalization. Minneapolis: University of Minnesota Press. 
Barker, J. 2005. "For Whom Sovereignty Matters." Introduction to Sovereignty Matters: Locations of Contestation and Possibility in Indigenous Struggles for Self-Determination, Joanne Barker, ed., 1-32. Lincoln, NE: University of Nebraska Press. https://doi.org/10.2307/j.ctt1dnncqc.4

2011. Native Acts: Law, Recognition, and Sovereignty. Durham, NC: Duke University Press.

Bateson, G with D. Jackson, J. Haley, J. Weakland. 1956. "Toward a Theory of Schizophrenia." Behavioral Science 1(4): 251-264.

https://doi.org/10.1002/bs.3830010402

Bengoa, J. and N. Caniguan. 2013. "Los Mapuches y el Bicentenario." In Mapuche: Procesos, Políticas, y Culturas en el Chile del Bicentenario. José Bengoa, ed. Santiago, Chile: Catalonia. https://doi.org/10.4067/s0718$\underline{65682013000200018}$

Bellei, C. 2013. "El fin de lucro como political educacional." In Los fines de la educación. J.E.García-Huidobro \& A.Falabella, ed. Santiago, Chile: CEPPE.

Black, J E. 2002. "The 'Mascotting' of Native America: Construction, Commodity, and Assimilation." American Indian Quarterly 26(4) https://doi.org/10.1353/aiq.2004.0003

Boas, F. 1895. "The social organization and the secret societies of the Kwakiutl Indians." In Report of the United States National Museum for the year ending June 30, 1895: pp. 309-738.

Bocarra, G. 2002. "The Mapuche People in Post-Dictatorship Chile." Études Rurales (163/164): 283-303.

https://doi.org/10.4000/etudesrurales.7984

Briggs, C. L. \& Bauman, R. 1992. "Genre, Intertextuality, and Social Power." Journal of Linguistic Anthropology 2(2): 131-172.

https://doi.org/10.1525/jlin.1992.2.2.131

Briones, Claudia. 2007. "Our Struggle Has Just Begun: Experience of Belonging and Mapuche Formations of Self." Indigenous Experience Today. Marisol de la Cadena and Orin Starn, eds. New York: Berg Publishers. https://doi.org/10.5040/9781474214933.ch-003

Brown, M. 2003. Who Owns Native Culture? Cambridge, MA: Harvard University Press.

Bruchac, M 2018. "Broken Chains of Custody: Possessing, Dispossessing, and Repossessing Lost Wampum Belts." Proceedings of the American Philosophical Society 162(1): 56-105.

Brubaker, R. 2004. Ethnicity Without Groups. Cambridge, MA: Harvard University Press.

Bunten, A. 2008. "Sharing culture or selling out: Developing the commodified persona in the heritage industry." American Ethnologist 
35(3): 380-395. https://doi.org/10.1111/i.1548-1425.2008.00041.x

2015. So how long have you been Native? Life as an Alaska Native Tour Guide. Lincoln, NE: University of Nebraska Press.

https://doi.org/10.5860/choice.193702

Carrier, J.G. 2018. "Moral Economy: What's in a name?" Anthropological Theory 18(1): 18-35.

Cattelino, E. 2008. High Stakes: Florida Seminole Gaming and Sovereignty. Durham, NC: Duke University Press. https://doi.org/10.1086/649634 2010. "The Double-Bind of American Indian Need-Based Sovereignty." Cultural Anthropology 25(4): 235-262 https://doi.org/10.1111/j.1548-1360.2010.01058.x

Cerda, R. 2009. "Situación Socioeconómica de los Mapuches." Puntos de Referencia 314(1). Santiago, Chile: Centro de Estudios Públicos. https://doi.org/10.38178/cep.vi113.445

Chambers, E. 2010. Native Tours: The Anthropology of Travel and Tourism. 2nd Edition. Long Grove, IL: Waveland Press.

Clarke, K. and D. Thomas. 2006. "Introduction," Globalization and Race: Transformations in the Cultural Production of Blackness, K. Clarke and D. Thomas, eds, 1-34. Durham, NC: Duke University Press. https://doi.org/10.1215/9780822387596-001

Collins, P. 2008. "New commodities, new consumers: Selling blackness in a global marketplace." Ethnicities 6 (3). https://doi.org/10.1177/1468796806068322

Comaroff, J. \& J. Comaroff. 2009. Ethnicity, Inc. Chicago, IL: University of Chicago Press. https://doi.org/10.7202/045716ar

Constable, N. 2009. "The Commodification of Intimacy: Marriage, Sex, and Reproductive Labor." Annual Review of Anthropology 38: 49-64. https://doi.org/10.1146/annurev.anthro.37.081407.085133

Coombe, R. 1998. The Cultural Life of Intellectual Properties. Durham, NC: Duke University Press.

Di Giminiani, Piergiorgio. 2018. Sentient Lands: Indigeneity, Property, and Political Imagination in Neoliberal Chile. Tuscon, AZ: University of Arizona Press. https://doi.org/10.2307/j.ctv5vdd94

2012. Tierras ancestrales, disputas contemporáneas: Pertenencia y demandas territoriales en la sociedad mapuche rural. Santiago: Ediciones UC.

Dunham, J. and A. DeCapua. 2007. "The pragmatics of advice giving: Cross-cultural perspectives." Intercultural Pragmatics 4 (3). https://doi.org/10.1515/ip.2007.016

Erazo, J. 2013. Governing Indigenous Territories: Enacting Sovereignty in 
the Ecuadorian Amazon. Durham, NC: Duke University. https://doi.org/10.1215/9780822378921

Errington, J. 2003. "Getting Language Rights: The Rhetoric of Language Endangerment and Loss." American Anthropologist 105(4): pp. 723-732. https://doi.org/10.1525/aa.2003.105.4.723

Ferguson, X. 1959. "Diglossia." Word 15(2): 325-340.

Fishman, J. 1991. Reversing language shift: Theoretical and empirical foundations of assistance to threatened languages. Clevedon, PA: Multilingual Matters. https://doi.org/10.1017/s0047404500017711

Foucault, M. 1991. "Governmentality." In The Foucault Effect: Studies in Governmentality, Graham Burchell, Colin Gordon and Peter Miller, eds., 87-104. Chicago: University of Chicago Press. https://doi.org/10.1017/s0829320100002507

French, B. 2012. "The Semiotics of Collective Memory." Annual Review of Anthropology 41: 337-353

Godelier, M. 1996. The Enigma of the Gift. Cambridge, UK: Polity Press. Gustafson, B. 2009. New Languages of The State: Indigenous Resurgence And The Politics Of Knowledge In Bolivia. Durham, NC: Duke University Press.

Harkin, M E. 2001. "Potlatch in Anthropology." International Encyclopedia of the Social and Behavioral Sciences, N J. Smelser and P B. Baltes, eds., Vol. 17: 11885-11889. Oxford: Pergamon Press. https://doi.org/10.1016/b008-043076-7/00942-6

Harrison, R. with T. Newholm, D. Shaw, eds. 2005. The Ethical Consumer. London: SAGE.

Haughney, D. 2006. Neoliberal Economics, Democratic Transition, And Mapuche Demands For Rights in Chile. Gainesville: University Press of Florida. https://doi.org/10.1017/s0022216x07003318

Heller, M. 2010. "The Commodification of Language". Annual Review of Anthropology 39: 101-114.

Horkheimer, M and T Adorno. 2002 [1947]. Dialectic of Enlightenment. Palo Alto, CA: Stanford University Press.

Jakobson, R. 1960. "Linguistics and poetics." In Style in language. T Sebeok, ed. Cambridge: M.I.T. Press.

Kant, I. 1996. "Groundwork for the Metaphysics of Morals." In Kant's Practical Philosophy, M J. Gregor, trans. Cambridge University Press, Cambridge.

Kaplan, M. 2007. "Fijian Water in Fiji and New York: Local Politics and a Global Commodity." Cultural Anthropology 22(4): 685-706.

https://doi.org/10.1525/can.2007.22.4.685 
Landier, A. and V. Nair. 2008. Investing for Change: Profit from Responsible Investment. New York: Oxford University Press.

Lukács, G. 1971 [1923]. History and Class Consciousness, R. Livingstone, trans. Cambridge, MA: MIT Press.

Luna Figueroa, L. 2015. "Educación Mapuche e Interculturalidad: Un analisis crítico desde una etnografía escolar." Chungara: Revista De Antropología Chilena 47 (4). https://doi.org/10.4067/s0717$\underline{73562015005000040}$

Luna Figueroa, L. with C. Bolomey and N. Caniguan Velarde. 2017. "Educación Mapuche en el Chile Neoliberal: Analisis de tres escuelas de la region de la Araucanía." Sinéctica 25 (1).

Malinowski, B. 2002 [1922]. Argonauts of the Western Pacific. New York: Routledge.

Mallon, F. 2005. Courage Tastes of Blood: The Mapuche Community of Nicolas Ailio and the Chilean State, 1906-2001. Durham, N.C.: Duke University Press. https://doi.org/10.1215/9780822387268

Mauss, M. 1925. The Gift: The Form and Reason of Exchange in Archaic Societies, W.D. Halls, trans. New York: W.W. Norton.

Mayol, Alberto. 2012. No al Lucro. De la Crisis del Modelo a la Nueva era Política. Santiago: Debate. https://doi.org/10.24201/fi.v0i0.2285 Mazzarella, W. 2004. "Culture, Globalization, Mediation." Annual Review of Anthropology 33: 345-67.

Millalén, P. J. 2006. Escucha, Winka!: Cuatro Ensayos de Historia Nacional Mapuche y un Epílogo sobre el Futuro. Santiago: LOM Ediciones. https://doi.org/10.4067/s0717-71942013000100007

Miller, D. 2012. Consumption and its Consequences. Boston, MA: Polity Press.

Moore, R. 1999. "Endangered." Journal of Linguistic Anthropology 9(1-2): 65-68.

Moore, R, S. Pietikäinen \& J. Blommaert. 2010. "Counting the losses: Numbers as the language of language endangerment." Sociolinguistic Studies 4(1). 1-26. https://doi.org/10.1558/sols.v4i1.1

Nash, K. 2000. "Global Integration and the Commodification of Culture." Ethnology 39(2): 129-131.

Ong, A. 2006. Neoliberalism as Exception: Mutations in Citizenship and Sovereignty. Durham, NC: Duke University Press.

Ortiz, P. 2009. "Indigenous Knowledge and Language: Decolonizing Culturally Relevant Pedagogy in a Mapuche Intercultural Bilingual Education Program in Chile." Canadian Journal of Indigenous Education 32(1): 93-114. 
Palomino-Schalscha, L. 2018. "Beyond Neoliberalism and Nature: Territoriality, Relational Ontology, and Hybridity in a Tourism Initiative in Alto Bío-Bío, Chile." In Indigenous Tourism Movements, Alexis Celeste Bunten, Nelson H.H. Graburn, eds. Toronto: University of Toronto Press. https://doi.org/10.3138/9781442622531-014

Park, Y-J and P. Richards. 2007. "Negotiating Neoliberal Multiculturalism: Mapuche Workers in the Chilean State." Social Forces 85(3): 1319-1339. https://doi.org/10.1353/sof.2007.0050

Polanyi, K. 1957. The Great Transformation: The Political and Economic Origins of Our Time. Boston, MA: Beacon Press.

Postero, N. 2007. Now We Are Citizens: Indigenous Politics in Postmulticultural Bolivia. Palo Alto, CA: Stanford University Press.

Radcliffe, S. and A. Webb. 2015. "Subaltern Bureaucrats and Postcolonial Rule: Indigenous Professional Registers of Engagement with the Chilean State." Comparative Studies in Society and History 57(1): 248-273. https://doi.org/10.1017/s0010417514000668

Richards, P. 2013. Race and the Chilean Miracle: Neoliberalism, Democracy, and Indigenous Rights. Pittsburgh, PA: University of Pittsburgh. https://doi.org/10.4000/nuevomundo.65914

Rose, N and P Miller. 1992. "Political Power Beyond the State: Problematics of Government." British Journal of Sociology 43(2): 173-205 https://doi.org/10.2307/591464

Ryan, C. 2005. "Introduction" in Indigenous Tourism: The Commodification and Management of Culture, Ryan, Chris and Michelle Aicken, eds. Oxford: Elsevier.

Sahlins, M. 2017 [1972]. Stone Age Economics. London: Taylor \& Francis.

Scheper-Hughes, N. \& P. Bourgois. 2004. "Introduction: Making Sense of Violence." In Violence in War and Peace, N. Scheper-Hughes and P. Bourgois, eds. Hoboken, NJ. Wiley-Blackwell. https://doi.org/10.1093/acprof:oso/9780190221447.001.0001

Scott, J C. 1976. The Moral Economy of the Peasant. New Haven: Yale University Press.

Seguin, M. 1986. "Understanding Tsimshian 'Potlatch.'" In: Native Peoples: The Canadian Experience, ed. by R. B Morrison and C. R Wilson, pp. 473500. Toronto: McClelland and Stewart.

Shever, E. 2012. Resources for Reform: Oil and Neoliberalism in Argentina. Palo Alto, CA: Stanford University Press. https://doi.org/10.1111/plar.12100

Simpson, A. 2014. Mohawk Interruptus: Political Life Across Two Settler States. Durham, NC: Duke University Press. https://doi.org/10.1111/plar.12232 
Smith, R. 2003. Stories of Peoplehood. New York: Cambridge University Press.

Taylor, M. 2006. From Pinochet to the 'Third Way': Neoliberalism and Social Transformation in Chile. Ann Arbor, MI: Pluto Press.

Thompson, A.B. 2017. Do Good: Embracing Brand Citizenship to Fuel Both Purpose and Profit. New York, NY: AMACOM.

Thompson, E. P. 1971. "The Moral Economy of the English Crowd in the 18th Century" Past and Present 50: 76-136.

Urban, G. 2001. Metaculture: How Culture Moves Through the World. Minneapolis, MN: University of Minnesota Press.

Urcioli, B. 2008. "Skills and Selves in the New Workplace." American Ethnologist 35(2): 211-228.

Verbara, J.I., with H. Gundermann and R. Foerster. 2013. Estado, Conflicto Étnico, y Cultura: Estudios Sobre Pueblos Indígenas en Chile. Antofagasta, Chile: Universidad Catolica del Norte.

White, P. 2009. The Moral Case for Profit Maximization. Baltimore, MD: Lexington Books.

Wilson, P. 2003. "Ethnographic Museums and Cultural Commodification: Indigenous Organizations, NGOs, and Culture as a Resource." Latin American Perspectives 30(1): 162-180. https://doi.org/10.1177/0094582x02239203

Yashar, D. J. 2005. Contesting Citizenship in Latin America: The Rise of Indigenous Movements and the Postliberal Challenge. Cambridge:

Cambridge University Press. https://doi.org/10.1017/cbo9780511790966

Zorn, E. 2004. Weaving a Future: Tourism, Cloth, and Culture on an Andean Island. Iowa City, IA: University of Iowa Press.

https://doi.org/10.2307/i.ctt20q1vz9 
Marshall B. Knudson is a doctoral candidate in the department of anthropology at the University of Pennsylvania, where he studies cultural and linguistic anthropology. His dissertation, based on 24 months of ethnographic research with Mapuche language activists in southern and central Chile, examines indigenous language revitalization projects as a prism on ethnic group identity and cultural politics in a time of diasporic "ethnic resurgence." His research and teaching interests include social theory and the history of social thought; language and culture; social categorization and boundarymaking - race, ethnicity, caste, class, gender, nation; coloniality and indigeneity; social and political movements; speech, conversation, and discourse analysis; language structure and pedagogy; language shift and revitalization; organizations; Chile, Brazil, Latin America. 